\title{
Susceptibility of spring wheat cultivars and breeding lines to Septoria nodorum Berk.
}

\author{
"REIJO KARJALAINEN, "*AINO LAITINEN and *"TAPIO JUUTI \\ "Departments of Plant Pathology and Plant Breeding, University of Helsinki, \\ SF-00710 Helsinki 71, Finland \\ **The Hankkija Plant Breeding Institute, SF-04300 Hyrylä, Finland
}

\begin{abstract}
Screening techniques for detecting the susceptibility of spring wheat cultivars and breeding lines to Septoria nodorum Berk. were studied in trials carried out in southern Finland. Small screening plots were artificially inoculated with the pathogen and subsequent observations showed that the early cultivars Apu, Ulla, Hja 21600 and the late cultivar Tähti were the most susceptible. The rank correlation between field assessments from naturally infected plots and assessment from artificially inoculated small screening plots was moderately high.

The correlations between 1000 grain weight and disease severity were negatively significant in some susceptible cultivars, but also in some resistant cultivars A weak positive correlation between 1000 grain weight and disease severity was observed in some resistant and also in some susceptible varieties.

Although our results do not show consistent trends we conclude that the use of small screening plots is an effective means of detecting differences in symptom expression among breeding lines and cultivars.
\end{abstract}

\section{Introduction}

Genetic plant protection is on the way to playing an increasingly important role in controlling plant diseases. Recent economic calculations of the value of resistance breeding carried out, for example, in Sweden, Denmark, and England, show that resistance breeding is an inexpensive and an effective way to control many important plant diseases (STABEL 1977, SUNDELL 1979, DOODSON 1981, HAGBERG and GUSTAFSSON 1981). Furthermore, totally new possibilities may be provided by recent advances in molecular genetics where resistance genes are transferred using recombinant DNA-technology; thus reducing the time needed to breed disease resistant varieties (ELLINGBOE 1981, DAY 1981, HOWELL 1982, BARTON and BRILL 1983).

Septoria nodorum Berk. is an important necrotrophic pathogen of wheat and barley and it has caused severe losses of wheat crops in many countries (SHIPTON et al. 1971, EYAL 1981). In Finland S. nodorum has been a major wheat pathogen too (MÄKELÄ 1975), although no economic assessment of 
the pathogen has been done. However, there is every reason to assume that during the previous rainy seasons $S$. nodorum has caused significant yield and quality reductions in Finnish wheat crops (MÄKELÄ 1979, KARJALAINEN and LAITINEN 1982).

Several measures, such as chemical control, crop rotation and resistant cultivars have been used to control $S$. nodorum (EYAL 1981). One of the major obstacles in utilizing the resistance of wheat to $S$. nodorum is the lack of single resistance genes that give an easily detectable level of resistance (BAKER 1978, EYAL 1981). The resistance is probably polygenically determined (SCOTT et al. 1982), and cultivars react to the disease to different degrees (BAKER 1978). Although there are no entirely resistant cultivars or lines (KRUPINSKY et al. 1977, BAKER 1978), considerable empirical evidence indicates that an adequate level of resistance is available for use in practical resistance breeding (SCOTT et al. 1982). Further, SCOTT et al. (1982) have suggested that the lack of efficient screening methods rather than the lack of resistance sources is the main hindrance in breeding for resistance to $S$. nodorum.

Several screening techniques are currently being used in breeding for resistance of wheat to $S$. nodorum, but these methods are difficult to reproduce and many results have been contradictory. The same cultivars have reacted in different ways to the disease, probably because different procedures have been used (RUFTY et al. 1980). The central idea of the screening method is based on the fact that the life cycle of $S$. nodorum requires humid conditions. The release and dispersion of conidia and the germination and growth of germ tubes requires a wet leaf surface (SHIPTON et al. 1971, POLLEY and CLARKSON 1978, UBELS 1979, JEGER et al. 1981). Frequent rains associated with moderate temperatures, that is $12-25^{\circ} \mathrm{C}$, provide favourable conditions for disease build-up in wheat fields (POLLEY and CLARKSON 1978, EYAL 1981). Since the above humid weather does not always prevail under natural conditions, wheat leaves have been kept damp in several artificial ways such as enclosing the plants in plastic bags or humid boxes or repeatedly irrigating them (SCOTT and BENEDIKZ 1977, UBELS 1979, P. R. SCOTT and P. W. BENEDIKZ 1982 pers. comm.). Conidia suspensions, infected straw, and natural infection, for instance, have all been used as inoculum (SCOTT and BENEDIKZ 1977, RUFTY et al. 1981), and these forms of inoculum have been provided at the mature plant stage (BRÖNNIMANN 1968 b, SCOTT and BENEDIKZ 1977) or the seedling plant stage (KIETREIBER 1962, SCHAREN and KRUPINSKY 1978). The measurement of disease resistance is based on the percent area of the leaf and ears of a cultivar that is attacked by the disease (BRÖNNIMANN 1968 a). BRÖNNIMANN (1968 b, 1982) has used the loss of 1000 grain weight as a measure of tolerance of wheat cultivars to $S$. nodorum.

In England, SCOTT and BENEDIKZ (1977) have evaluated methods for screening wheat cultivars to $S$. nodorum at the mature plant stage by using small artificially inoculated plots that were kept damp with the use of plastic bags and repeated irrigation. They found this method an efficient way to screen breeding lines, and cultivars, and it is well suited for practical 
resistance breeding. The idea of using mature plant tests is based on the relevant information that $S$. nodorum causes most damages at later growth stages, and several growth factors, such as height and maturation time affect the expression of resistance under field conditions (BRÖNNIMANN 1968, EYAL 1981, FRIED and BRÖNNIMANN 1982).

In the present paper we test the validity of the screening method developed by SCOTT and BENEDIKZ (1977). The susceptibility of several Finnish cultivars and breeding lines as well as foreign resistant sources are evaluated. The association of disease severity to grain weight, plant height and maturation time is discussed.

\section{Materials and methods}

\section{Isolation and culturing of the fungus}

Septoria nodorum was isolated from infected wheat leaves, which had been surface sterilized (in $1 \%$ sodium hypochloride) for 3 minutes and then transferred onto agar. The cultures were grown on oatmeal agar in petri dishes under near-ultraviolet irradiation for $6-10$ days at $19-22{ }^{\circ} \mathrm{C}$. The NUV-light has been shown to stimulate the pycnidia formation of $S$. nodorum (COOKE and JONES 1970). It was necessary to make some spore transfers to obtain densely sporulating cultures. KRUPINSKY and SCHAREN (1973) have suggested that dense sporulation ability is a characteristic associated with virulence. It was also necessary to avoid using old cultures because they had lost their aggressivity (SCHAREN and KRUPINSKY 1973). The plates were flooded with a small amount of sterile water, and the cirrhi containing pycnidiospores were removed by gently rubbing the agar surface with a glass rod. The conidia suspension was filtered through some layers of cheesecloth. A spore concentration of $10^{6}$ conidia/ml as well as a higher concentration (as determined with the use of a heamacytometer) were the inoculum densities used, as suggested by earlier experiments (KRUPINSKY 1976, EYAL and SCHAREN 1977). To obtain better adherence of the conidia to wheat leaves some surfacant was added.

\section{Plant material}

Finnish spring wheat cultivars and breeding lines were evaluated in comparison with resistant lines and cultivars obtained from the following institutes: Svalöf AB, Cambridge Plant Breeding Institute, The Swiss Agricultural Research Station, USDA Beltswille, and Department of Farm Crops, Norway.

\section{Experimental procedure}

The preliminary experiment was carried out in 1981, and the data presented in this paper are based on 1981 and 1982 trials carried out at the Hankkija Plant Breeding Institute. The experimental design was mainly based on the paper by SCOTT and BENEDIKZ (1977). 
Small plots $\left(0.3 \mathrm{~m}^{2}\right)$ with three replications in the year 1981 and four replications in 1982 were used for inoculation, and one replication in 1981 and two in 1982 were used as uninoculated controls. Inoculum was applied onto the plants by spraying soon after ear emergence at the rate of $20 \mathrm{ml} /$ plot. After inoculation the plants were kept damp by covering them with plastic bags for 48 hours, followed by daily irrigation depending on the prevailing weather.

The assessment of disease severity was made on the flag leaves and ears of 20 randomly labelled stems by estimating the percentage area covered by $S$. nodorum lesions. The assessment was made 7-10 days after the inoculation. Plant height, heading date and ripening time were observed and yield/ear and yield components were counted from harvested ears.

\section{Field observations}

Spring wheat variety trials carried out at the Hankkija Plant Breeding Institute were used as sources for observing disease development on different cultivars in the years 1980,1981, and 1982. During the 1981 growing season four observation times were used, and data was collected for 20 randomly selected and labelled stems/plot. Disease observations were made on the flag leaves and the second leaves in four replications.

\section{Statistical analyses}

Because of large intraplot variation in disease observations in the screening test, only means are presented in order to show that the results represent relative values. The foliar disease severity figures are based on the results of the 1981 experiment only since in 1982 the exceptionally high temperatures masked the differences between cultivars.

The rank correlation between the field and screening tests is calculated. The correlations between disease severity and maturation time, height and 1000 grain weight are calculated. The percentage diseased leaf area values of the wheat leaves were transformed using the arc-sin transformation.

\section{Results}

\section{Field observations of cultivar susceptibility}

The development of $S$. nodorum on the upper leaves of several Finnish and two Swedish spring wheat cultivars at the Hankkija Plant Breeding Institute is presented in Fig. 2. During the wetter season, 1981, the disease progressed rapidly from the lower part of the canopy to the upper part of the canopy of susceptible varieties. Generally, the early cultivars like Apu, Ulla and Luja, as well as medium early/late cultivars such as Hankkija's Taava, Ruso and Hankkija's Tapio were detected to be the most susceptible to attack by $S$. nodorum. It seems evident from Fig. 2 that late cultivars such as Tähti, Kadett and Drabant escaped the disease outbreaks during the early part of the 
season and thus are more resistant at certain observation times. However, the disease may progress rapidly in the latter half of the season on susceptible varieties. During the 1982 season the disease spread was prevented by rather high temperatures and a long dry period (Fig. 1).

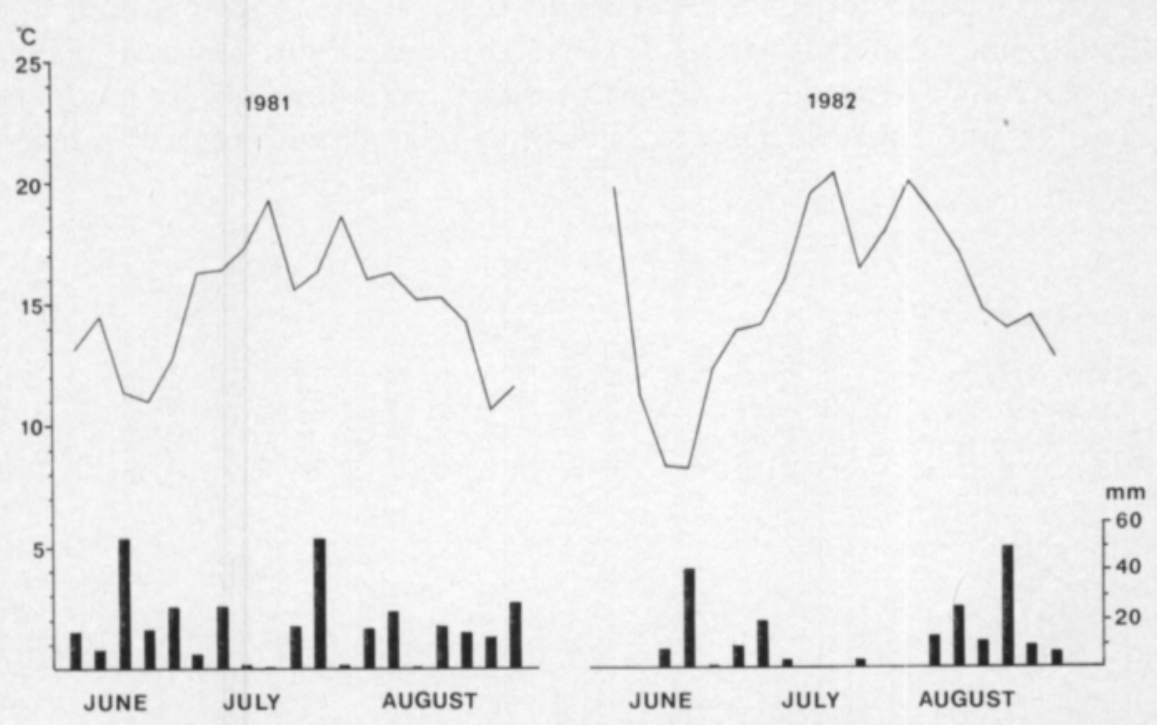

Fig. 1. Monthly averages of temperatures $\left({ }^{\circ} \mathrm{C}\right)$ and monthly precipitation $(\mathrm{mm})$ between June and August in 1981 and 1982 at the Experimental Farm of Anttila.

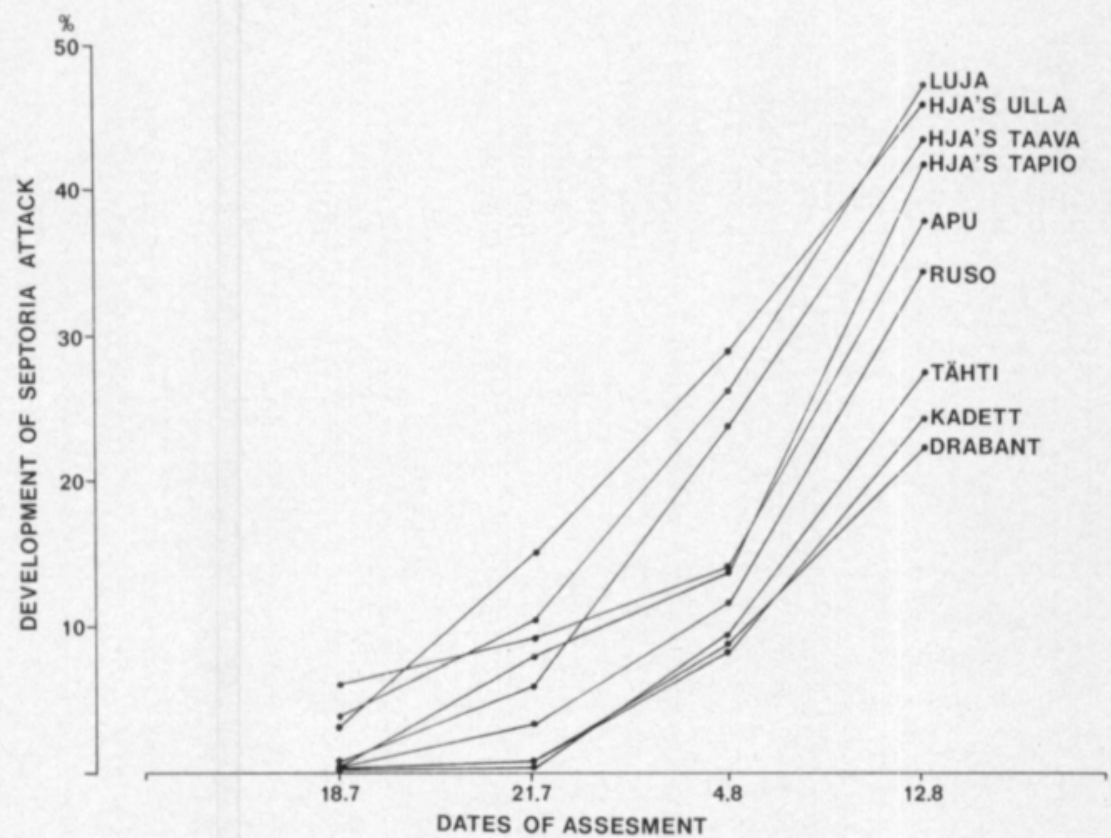

Fig. 2. The development of $S$. nodorum on the upper leaves of several Finnish and two Swedish spring wheat cultivars in variety trials carried out at the Experimental Farm of Anttila in 1981. 
Assessment of cultivar susceptibility by the artificial field technique

Artificial field inoculation with $S$. nodorum suspension revealed that early cultivars such as Apu, Ulla, Hankkija's 21600 and Kolibri were fairly susceptible with regard to the flag leaf assessment parameter (Fig. 3). Another clear difference is evident in Fig. 3 since the late Finnish cultivar Tähti and the foreign resistant sources CI 1340 and Allen appear to be fairly susceptible. Flag leaf resistance to $S$. nodorum seems to be at the moderate level in the following lines and cultivars: CI 12463, Brodda, Pilot, Garnet, 80149, T 7347 , Norröna and Kadett. The rest of the tested cultivars were moderately susceptible and it was difficult to rank these reliably with regard to flag leaf severity.

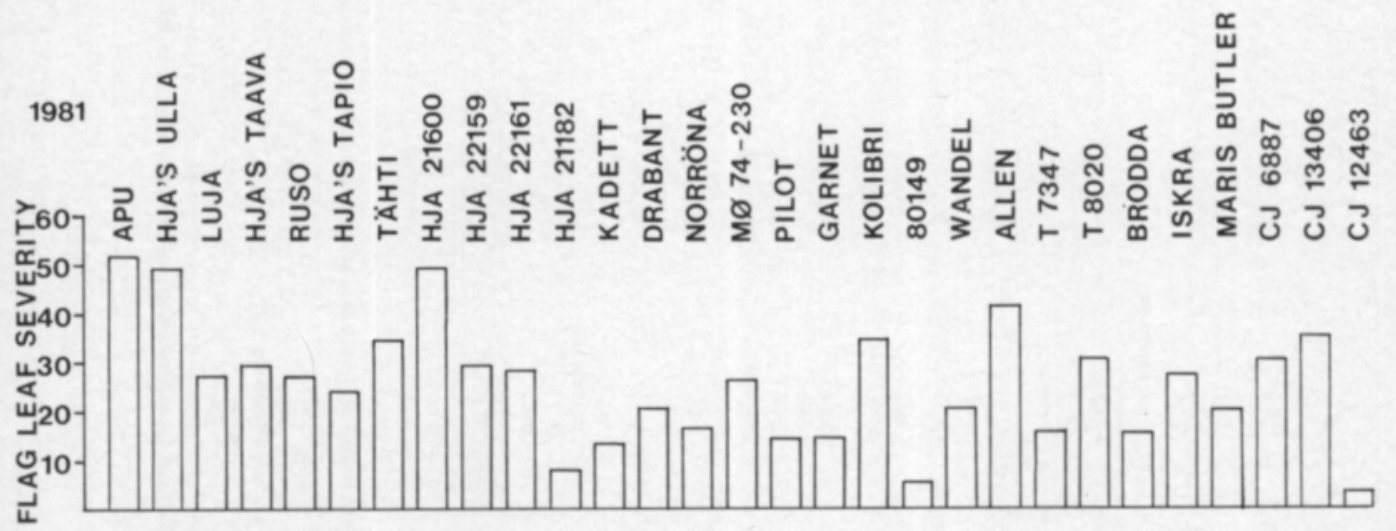

Fig. 3. Leaf susceptibility to $S$. nodorum of spring wheat cultivars and breeding lines in 1981 as revealed by artificial screening test.

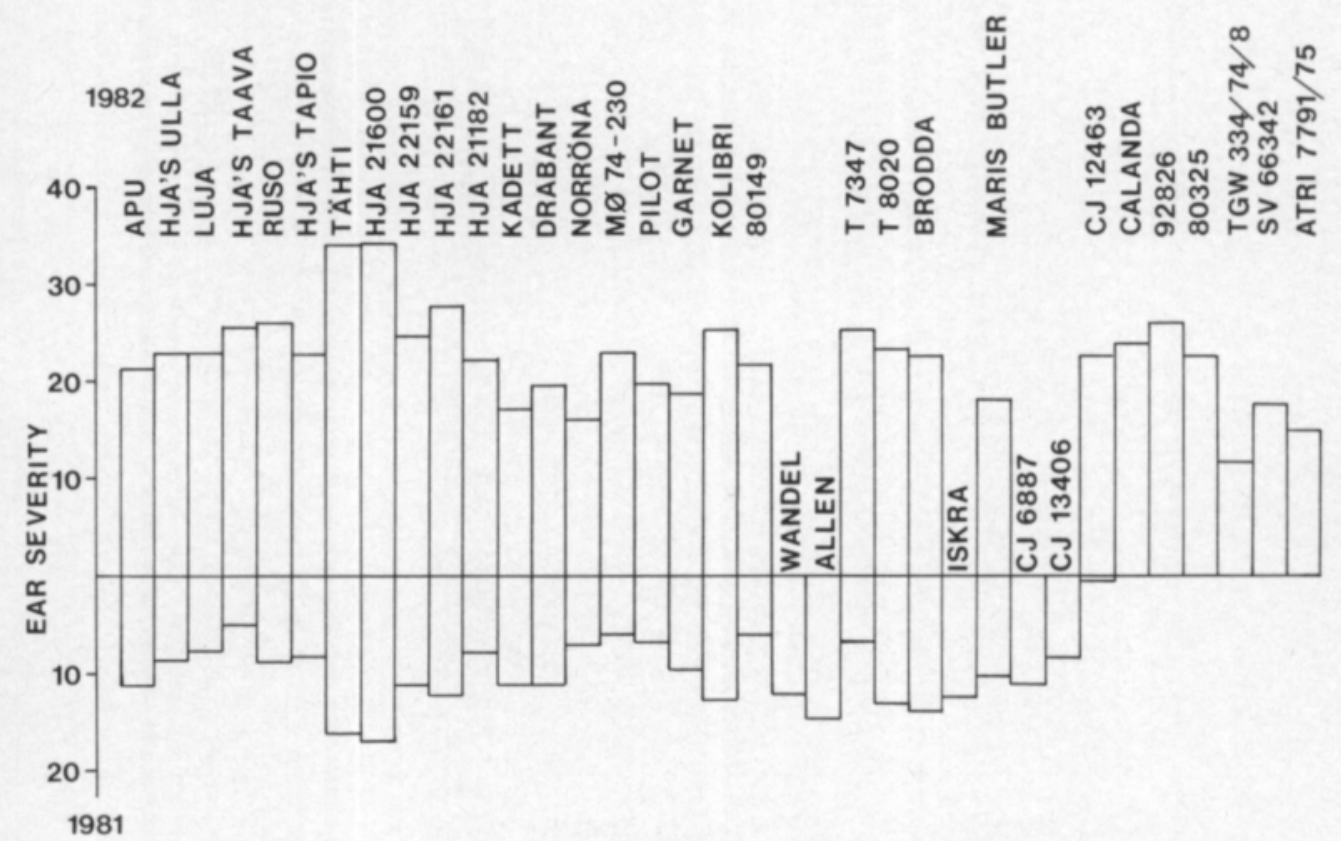

Fig. 4. Ear susceptibility to $S$. nodorum of spring wheat cultivars and breeding lines in 1981 and 1982 as revealed by artificial screening test. 
The susceptibility of ears to $S$. nodorum is presented in Fig. 4. The figures of 1981 are generally smaller than those of 1982 , which were based on several observations in the later developmental stages. In both years the cultivar Tähti and the line Hankkija's 21600 were detected to be the most heavily attacked by the disease. Norröna, Pilot, and Garnet were less severely attacked by $S$. nodorum in both years. The foreign resistant sources TGW and Atri had fairly good ear resistance in the year 1982 .

No consistency was observed between two years with regard to ear resistance. This was particularly obvious on cultivars like CI 12463, T 7347, Mø 74-230, 80149, Taava and Hankkija's 21182, which had a low level of disease in 1981 but were rather heavily attacked in 1982.

The correlation between flag leaf and ear susceptibility was positively significant $(r=0.55, p<0.01)$ and shows that generally these two characters are valid for differentiating the cultivars. The relationship between the field assessment of cultivar susceptibility and the artificial field test is presented in Fig. 5. The Spearman rank correlation $(r=0.56)$ is fairly high. It seems from Fig. 5 that the cultivars Luja and Tapio deviate more than the other cultivars which might indicate that more observations are needed to be able to correctly rank these cultivars.

\section{Relationship between 1000 grain weight and disease severity}

The widely accepted idea that $S$. nodorum principally causes reduction in grain weight is evaluated on the base of an artificial field test (Fig. 6). The correlation between 1000 grain weight and flag leaf severity over all cultivars shows a weak negative correlation $(r=-0.24)$. The correlation between 1000 grain weight and ear severity is negatively significant $(r=-0.43, p<0.05)$.

Further attempts were made to test whether the resistant cultivars differ in their grain filling ability as compared with the susceptible ones after

Fig. 5. The relationship between the field assessment from naturally infected plots and artificially inoculated small screening plots.

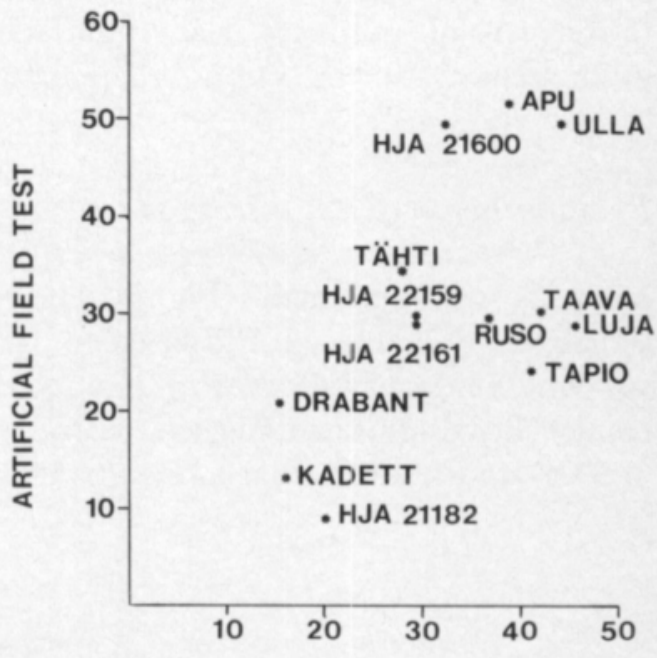

FIELD OBSERVATIONS 


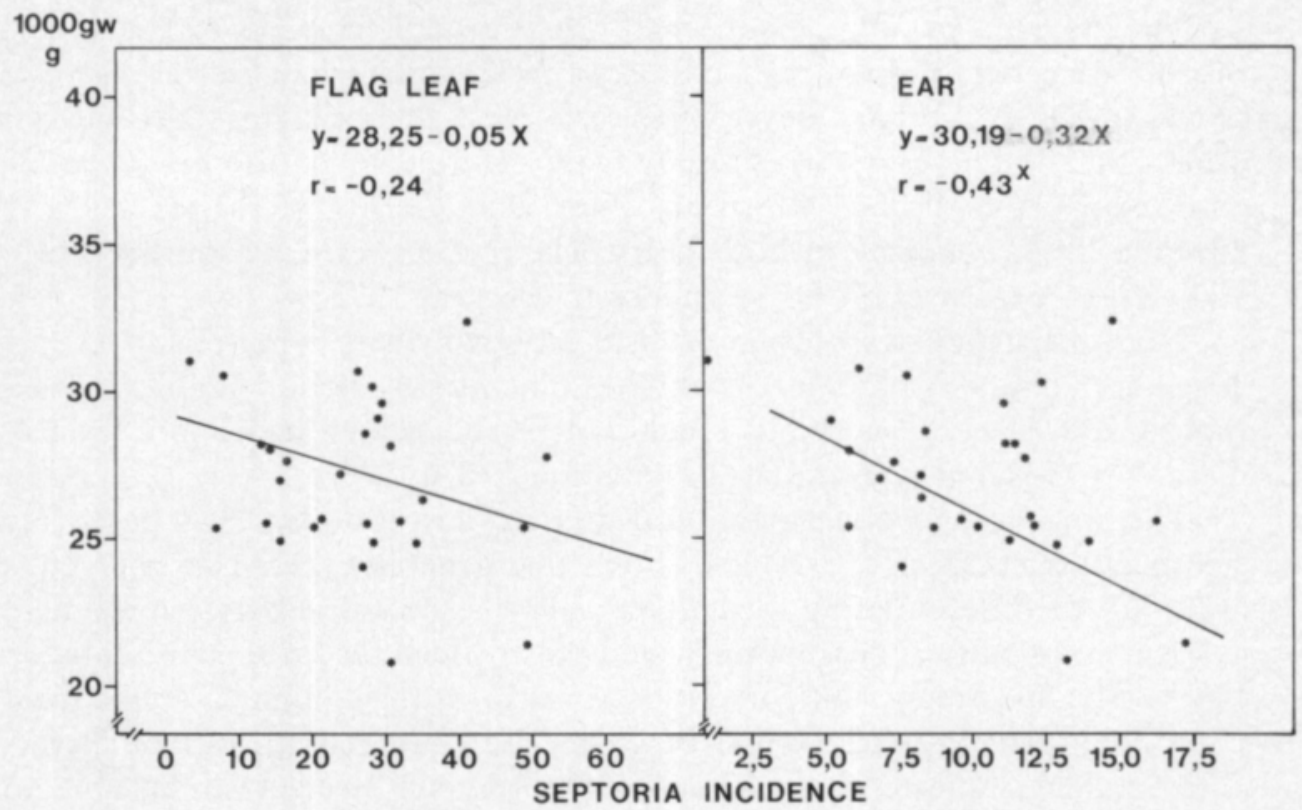

Fig. 6. The correlations between disease severity and grain weight using data from screening test.

inoculation with $S$. nodorum (Fig. 7). A clear negative correlation between disease severity and 1000 grain weight was detected in the following cultivars: Apu, Hankkija's Taava, Hankkija's Tapio, Tähti, Kadett and Drabant. A weak correlation between disease severity and 1000 grain weight was observed in the following cultivars: Hankkija's Ulla, Luja, Ruso, Brodda, Garnet and CI 12463. It is obvious that there is no consistent trend in the correlations between disease severity and grain weight. A particularly interesting point is that the susceptible varieties, Hankkija's Ulla and Luja (Figs. 2 and 3), were found to be fairly tolerant to attack by $S$. nodorum while the fairly resistant cultivars, Kadett and Drabant, seem to respond with lower grain weight after infection by the pathogen.

Relationship between disease severity and plant height and maturation time

To test the idea that disease severity is connected with plant height some computations were made (Fig. 8). The results indicate a negative correlation, but the coefficients were low. A similar approach was applied and tested to see whether maturation time is affected by disease severity (Fig. 9). The results show significant negative correlations $(r=-0.65, p<0.001, r=-0.36, p$ $<0.05)$ and indicate that late cultivars are more resistant than early ones. 


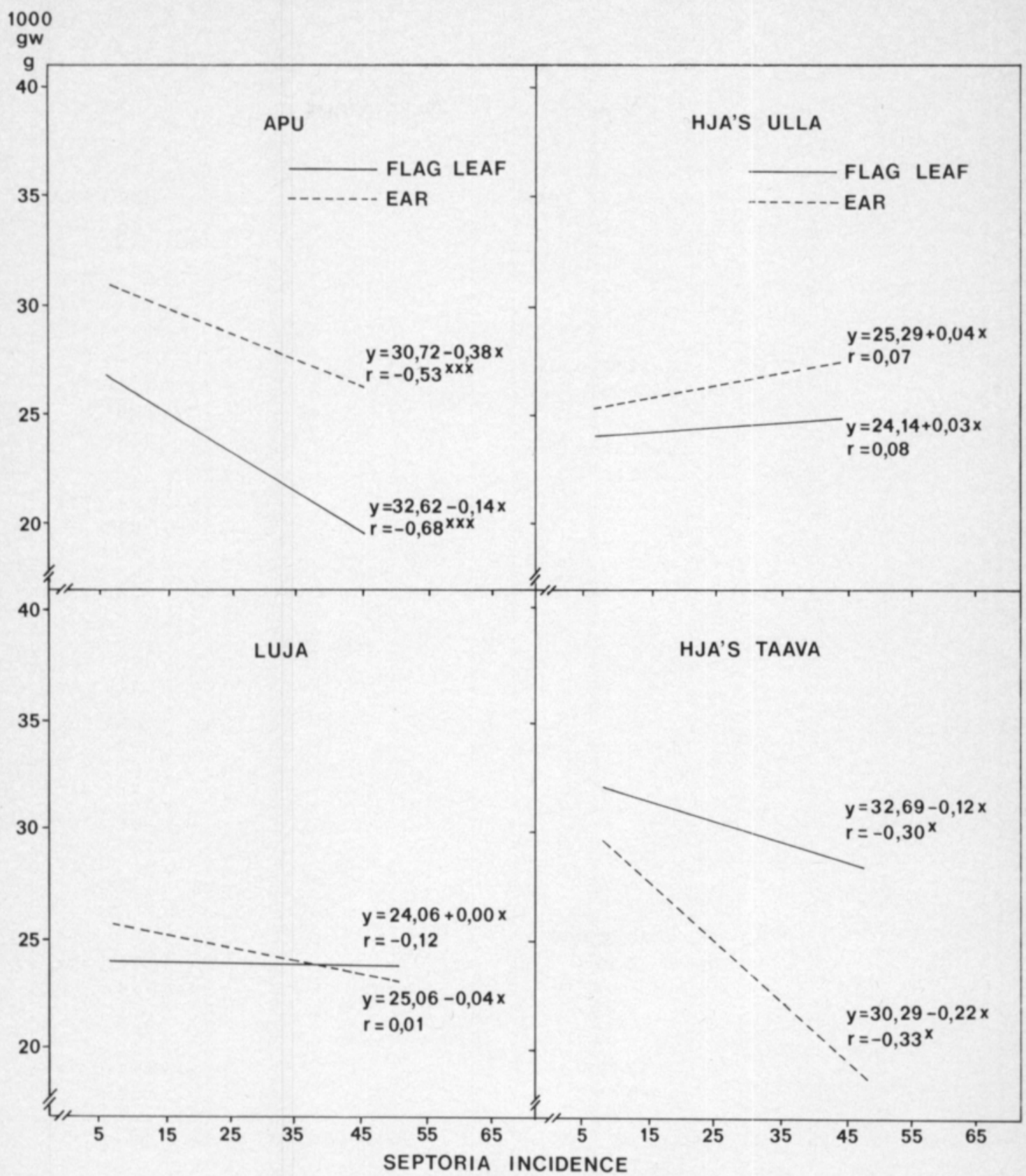

Fig. 7. The correlations between disease severity and grain weight on several susceptible and resistant cultivars. The data based on screening test. 


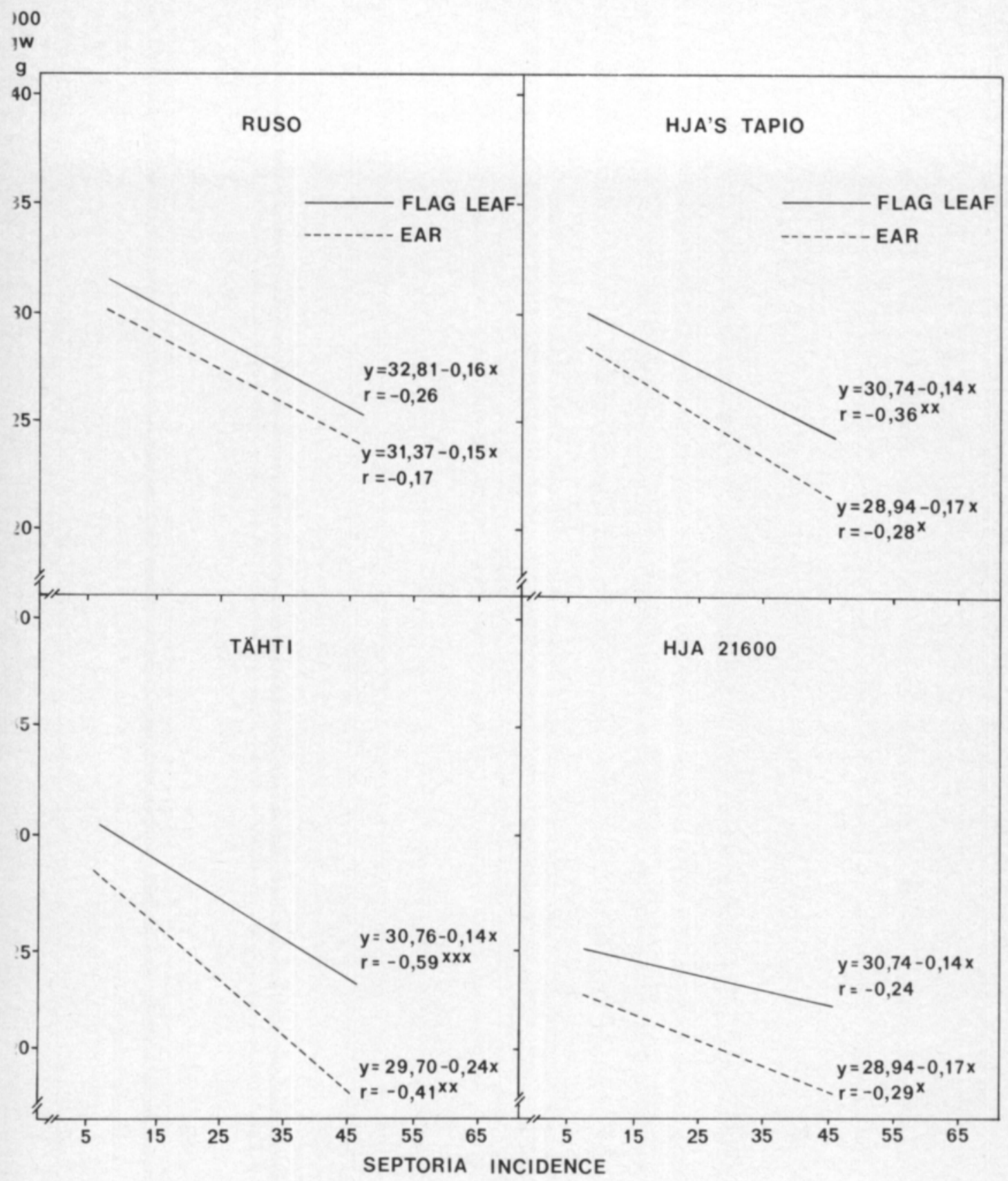




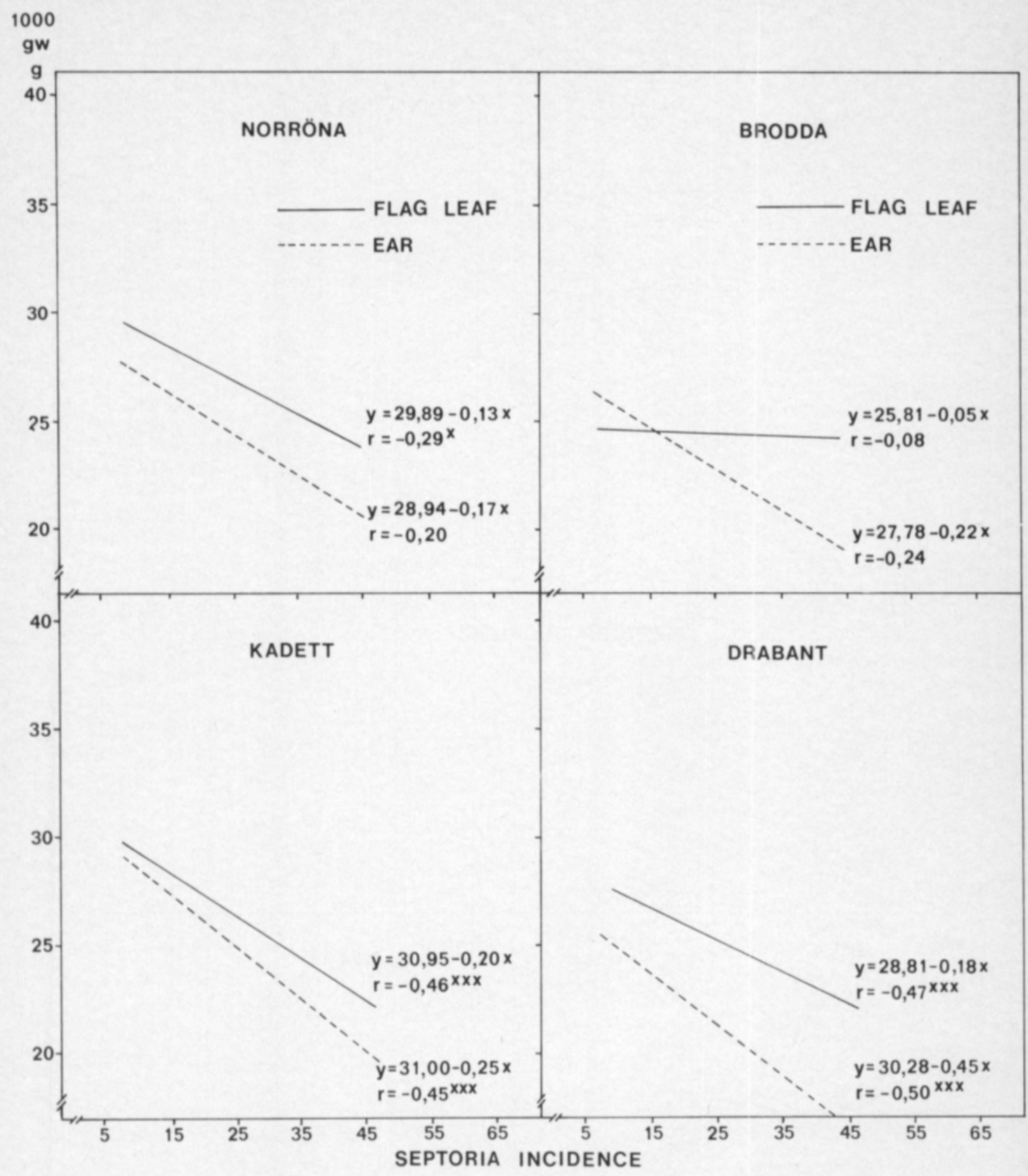



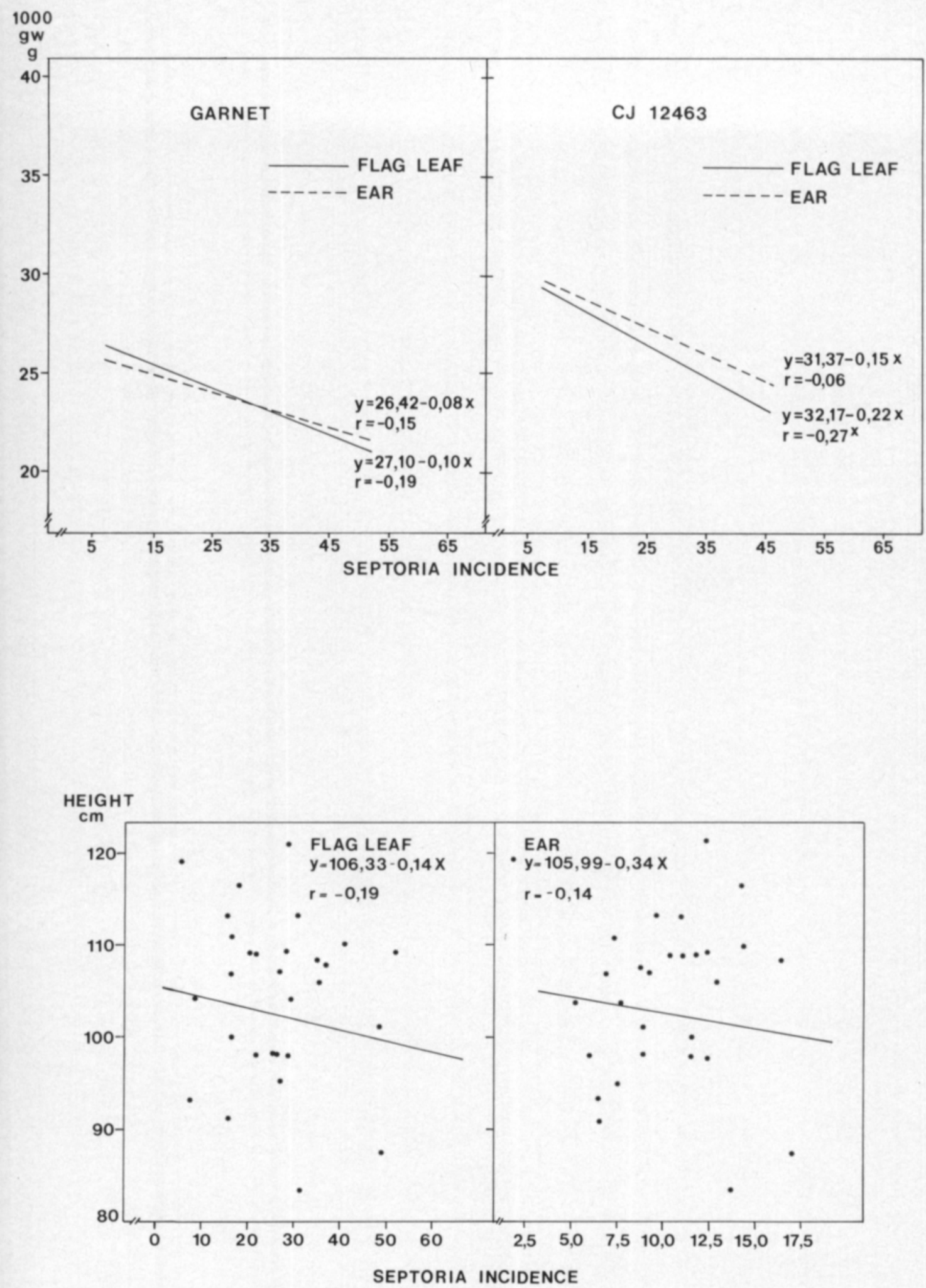

Fig. 8. The correlations between disease severity and plant height. 


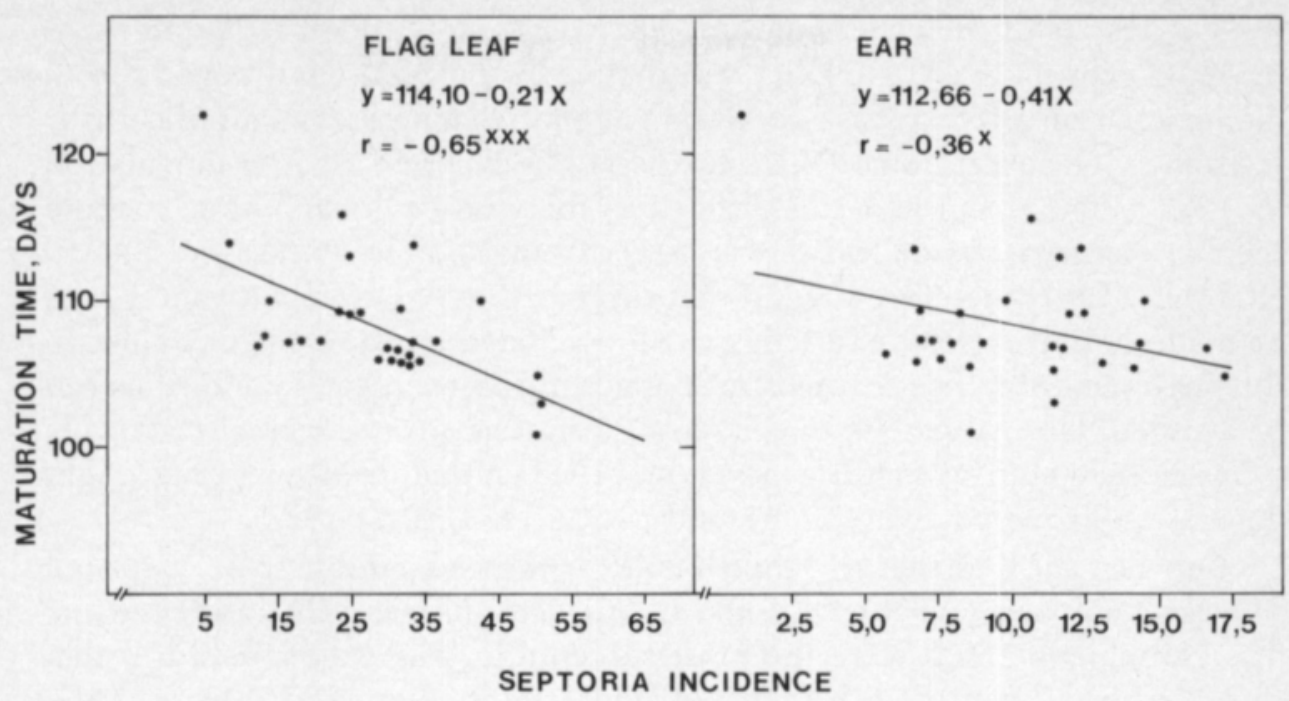

Fig. 9. The relationship between disease severity and maturation time.

\section{Discussion}

Inherent genetic variation and simple, inexpensive and reliable screening methods are the major requirements for successful resistance breeding (e.g. RUSSELL 1978). Septoria nodorum is mainly spread by rain-splashed drops, and inoculum sources within a crop are probably more important than external sources (GRIFFITHS and AO 1976, JENKYN and KING 1977, JEGER et al. 1981). Under natural conditions the disease is not often evenly spread over the experimental field (RUFTY et al. 1981). Therefore artificial inoculation is needed in order to test breeding lines and segregation populations against the disease (FRIED and BRÖNNIMANN 1982).

The artificial screening method developed by SCOTT and BENEDIKZ (1977) was tested in this study. The results confirm the validity of the method, since we found it to be rather efficient in distinguishing susceptible and resistant lines (Fig. 3). Only a small incidence of disease, which started late, occurred in the uninoculated controls and on this basis it was not possible to separate cultivars with regard to resistance. We came to the same conclusion as SCOTT and BENEDIKZ (1977) did, that is that the time of assessment is critical since clear differentiation between cultivars seems to persist only for 10-14 days, after which symptoms are masked by rapidly increasing senescence. An extra assessment was made in our experiments as we found that a great number of replications are required to obtain reliable differences between cultivars which have nearly the same level of resistance. Large intraplot variation between measured leaves probably indicates an uneven spread of applied inoculum. Recent improvements in inoculation techniques (EYAL and SCHAREN 1977, 1980, UBELS 1979) may overcome these difficulties and thus improve the reliability of screening techniques. 
The results of the experiment in 1982 corroborate the observation made by FRIED and BRÖNNIMANN (1982) that environmental conditions following inoculation affect disease development and reliable assessment of cultivar resistance. The exceptionally high temperatures experienced after inoculation in 1982 (Fig. 1) masked the differences between cultivars, thus making reliable comparisons of leaf disease severity impossible. FRIED and BRÖNNIMANN (1982) therefore suggest that comparisons between cultivars should be made only if different varieties were inoculated on the same day since in this way the differences caused by changes in environmental conditions can be avoided. Unfortunately, this may cause another problem because of wide differences in cultivar maturity levels and the fact that disease severity might depend on growth stage (COOKE and JONES 1971, OBST 1977).

Our test showed that all Finnish cultivars are susceptible to $S$. nodorum. The early cultivars, Apu, Ulla, Luja, and the late cultivar Tähti, and breeding line Hankkija's 21600 were the most susceptible. This study indicates that some cultivars such as CI 12463, Brodda, Pilot, Garnet, 80149, T 7347, Norröna, and Kadett, have a moderate level of resistance, and these can be used in practical resistance breeding.

Field observations of disease development confirm the previous observations that early cultivars are more liable to attack than late ones. In this study the artificial field test seemed to correlate fairly well with field observations, which may indicate that the artificial test reflects those differences occurring under field conditions, too.

The artificial field inoculation method with $S$. nodorum, followed by covering the plots with plastic bags, raises some important questions with regard to practical resistance breeding. First of all, plastic bags may disturb normal plant development and thus make it difficult to evaluate cultivars with regard to plant breeding characters, such as plant type and lodging resistance. One of the most powerful methods to solve these problems is the method where small plots are repeatedly irrigated and inoculated to insure disease development (P. R. SCOTT and P. W. BENEDIKZ 1982 pers. comm.). However, this method may need abundant inoculum due to the apparent loss of inoculum compared with the "plastic bag" method.

Attempts to test whether disease severity is associated with grain weight indicate that in some cultivars (Fig. 8, 9 and 10) there is a clear negative correlation, however with some cultivars which showed a susceptible reaction to the disease only a weak correlation was detected.

The detected inconsistency between grain weight and disease may be due to the observed fact that $S$. nodorum may affect yield without causing symptom expression (SCHAREN et al. 1975, OBST 1977). Moreover, our data reveal that in some cultivars like Ulla and Luja, weak correlation may be due to tolerance, thus supporting the ideas presented by BRÖNNIMANN (1968, $1969,1982)$.

However, tolerance is a fairly obscure concept, and it is difficult to define it critically (GAUNT 1981). Therefore, observed tolerance may sometimes be an artifact of experimental procedure. SCOTT and BENEDIKZ $(1977,1982)$ suggest that it is easier to select resistance on the basis of symptom expression 
rather than reduced yield loss. BRÖNNIMANN (1982) has recently demonstrated that reduced disease development has been observed in several tolerant lines.

There is now considerable empirical evidence accumulated to demonstrate that tall wheat cultivars are less liable to attacks by Septoria disease than short ones (BRÖNNIMANN 1968, 1969, SCOTT 1973). This relationship between plant height and disease resistance has been explained on the basis of the stepwise movement of the disease from the lower to the upper leaves and ears (SCHAREN 1964). The vertical progress of Septoria is affected by the distance between the lower leaves and the upper leaves and ears (BAHAT et al. 1980 , EYAL 1981), which may be the consequence of differences in microclimatic conditions (BAHAT 1980). Differences in crop morphology may be important under moderate epidemic conditions, since tall varieties may avoid damage by an escape mechanism (ROSIELLE and BROWN 1980, FRIED and BRÖNNIMANN 1982).

The results of our experiments indicate weak negative correlation between disease severity and plant height. This may be due to the fact that our test plants did not include any dwarf varieties and their genetic height variation was not so wide as in other experiments.

A number of experiments have also demonstrated that the best resistance is often found on late maturing cultivars (EYAL 1981). Our results confirm this theory since we found significant negative correlation between disease severity and maturity levels.

In breeding for spring wheat under northern conditions there are two important aims (excluding yield and quality), notably earliness and good lodging resistance, which often means moderately short straw. Therefore, resistance breeding against $S$. nodorum is faced with difficult problems, because there is ample evidence that Septoria resistance is positively correlated with late maturity and tallness (EYAL 1981, SCOTT et al. 1982). In their comprehensive study, SCOTT et al. (1982) conclude that breeding wheat cultivars with a high degree of resistance is difficult, if short straw or earliness is also an objective. However, there is evidence that new early and short wheat cultivars with a moderate resistance have been obtained (SCOTT et al. 1982), which indicates that deviations in correlations frequently occur. This study shows that many lines and cultivars with a moderate degree of resistance also mature fairly early and have a moderate level of height. Our study contributes to the suggestion by SCOTT et al. (1982) that progress in breeding for resistance of wheat to $S$. nodorum depends greatly on efficient screening and selection strategies.

In comparison with different control measures against $S$. nodorum resistance breeding has recently been shown to give good economic results in Britain (DOODSON 1981). Moreover, since no physiological races are recognized for this fungus, host resistance is probably durable and thus resistance breeding can provide long term protection.

Acknowledgement. We are grateful to Professors Eeva Tapio and Peter Tigerstedt for critical reading of the manuscript. We wish to thank Miss Eila Lonka and Mrs. Sinikka Karjalainen for technical 
assistance. The English text was kindly revised by Sinikka Karjalainen and Heather MacKenzie. The work was supported by grants from the Ministry of Agriculture and Forestry (to the University of Helsinki) and from the August Johannes ja Aino Tiuran maatalouden tutkimussäätiö. This support is gratefully acknowledged.

\section{References}

BAHAT, A., GELERNTER, J., BROWN, M. B. \& EYAL, Z. 1980. Factors affecting vertical progression of Septoria leaf blotch in short-statured wheats. Phytopath. 70: 179-184.

BAKER, G. A. 1978. "Septoria - the lurking threat to wheat yields". EPPO Bull. 8: 9-20.

BARTON, K. A. \& BRILL, W. J. 1983. Prospects in plant genetic engineering. Science 219: 671-676.

BRÖNNIMANN, A. 1968 a. Zur Kenntnis von Septoria nodorum Berk., dem Erreger der Spelzenbräune und einer Blattdürre des Weizens. Phytopath. Z. 61: 101-146.

- 1968 b. Zur Toleranz des Weizens gegenüber Septoria nodorum Berk. Phytopath. Z. 62: 365-370.

- 1969. Ursachen der unterschiedlichen Verträglichkeit des Weizens gegenüber Befall durch Septoria nodorum Berk. Phytopath. Z. 66: 353-364.

- 1982. Entwicklung der Kenntnisse über Septoria nodorum Berk. im Hinblick auf die Toleranz- oder Resistenzzühtung bei Weizen. Neth. J. Agric. Sci. 30: 47-62.

COOKE, B. M. \& JONES, D. G. 1970. The effect of near-ultraviolet irradiation and agar medium on the sporulation of Septoria nodorum and S. tritici. Trans. Br. mycol. Soc. 54: 221-226.

- 1971. The epidemiology of Septoria tritici and Septoria nodorum. III The reaction of spring and winter wheat varieties to infection by Septoria tritici and S. nodorum. Trans. Br. mycol. Soc. 56: 121-135.

DAY, P. R. 1981. Plant biochemistry - a cinderella too long. TIBS 6: I-II.

DOODSON, J. K. 1981. The economic contribution of resistant winter wheat varieties. J. Nat. Inst. agric. Bot. 15: 413-420.

ELLINGBOE, A. H. 1981. Changing concepts in host-pathogen genetics. Ann. Rev. Phytopath. 19: 125143.

EYAL, Z. 1981. Integrated control of Septoria diseases of wheat. Plant Disease 65: 763-768.

- \& SCHAREN, A. L. 1977. A quantitative method for the inoculation of wheat seedlings with pycnidiospores of Septoria nodorum. Phytopath. 67: 712-714.

FRIED, P. M. \& BRÖNNIMANN, A. 1981. Septoria nodorum: Epidemiologie und Vergleich von Selektionsmethoden. Ber. Arbetstagg. 1980, Arbeitsgem. Saatzuchtleiter Gumpenstein, 105-123.

- 1982. Septoria nodorum Berk. on wheat: Effect of inoculation time and penduncle length on yield reduction and disease development. Z. Pflanzenzüchtg. 89: 312-328.

GAUNT, R. E. 1981. Disease tolerance - an indicator of threshold? Phytopath. 71: 915-916.

GRIFFITHS, E. \& AO, H. C. 1976. Dispersal and spread of glume blotch in the field. Trans. Br. mycol. Soc. 67: 413-418.

HAGBERG, A. \& GUSTAFSSON, M. 1981. Resistensförädlingens möjligheter att minska användningen av kemiska bekämpningsmedel inom jordbruks- och trädgårdsnäringen. Sver. Utsädesför. Tidskrf. 91: 3-19.

HOWELL, S. H. 1982. Plant molecular vehicles: potential vectors for introducing foreign DNA into plants. Ann. Rev. Plant Physiol. 33: 609-650.

JEGER, M. J., GRIFFITHS, E. \& GARETH JONES, D. 1981. Influence of environmental conditions on spore dispersal and infection by Septoria nodorum. Ann. appl. Biol. 99: 29-34.

JENKYN, J. F. \& KING, J. E. 1977. Observations on the origins of Septoria nodorum infection of winter wheat. Plant Path. 26: 153-160.

KARJALAINEN, R. \& LAITINEN, A. 1982. Screening for resistance of spring wheat to Septoria nodorum. Nord. Jordbr.forskn. 64: 232-233.

KIETREIBER, M. 1962. Eine Labormethode für die Prüfung von Weizensorten auf Resistenz gegen Septoria nodorum Berk. Pflanzenschutzberichte 31: 179-188.

KRUPINSKY, J. M. 1976. Techniques for screening wheat for Septoria resistance In Proc. of Septoria diseases of wheat workshop (GUNFER, B. M. and NELSON, L. R., eds.), 28-32. Ga Agric. Exp. Station, Georgia. 
— , GRADDOCK, J. C. \& SCHAREN, A. L. 1973. Septoria resistance in wheat. Plant Dis. Reptr. 61: 632-636.

LITTLE, R. \& DOODSON, J. K. 1974. A technique for assessing the reaction of wheat varieties to Septoria nodorum (Berk.) infection and the preparation of recommended list figures. J. Nat. Inst. Agric. Bot. 13: 152-159.

MÄKELÄ, K. 1975. Occurrence of Septoria species on cereals in Finland in 1971-1973. J. Scient. Agric. Soc. Finl. 47: 218-244.

- 1979. Sadekesiä suosivat vehnän Septoria-taudit. Koetoim. ja Käyt. 6.3.

OBST, A. 1977. Untersuchungen zur Epidemiologie, Schadwirkungen und Prognose der Spelzenbräune (Septoria nodorum) des Weizens. Bayr. Landw. Jb. 54: 72-117.

POLLEY, R. W. \& CLARKSON, J. D. S. 1978. Forecasting cereal disease epidemics In Plant Disease Epidemiology (SCOTT, P. R. and BAINBRIDGE, A., eds.), pp. 141-150. Blackwell Sci. Publ. Oxford.

ROSIELLE, A. A. \& BROWN, A. G. P. 1980. Selection for resistance to Septoria nodorum in wheat. Euphytica 28: 337-346.

RUFTY, R., HEBERT, T. T. \& MURPHY, C. F. 1981. Evaluation of resistance to Septoria nodorum in wheat. Plant Disease 65: 406-409.

RUSSELL, G. E. 1978. Plant breeding for pest and disease resistance. Butterforts, London.

SCHAREN, A. L. 1966. Cyclic production of pycnidia and spores in dead wheat tissue by Septoria nodorum. Phytopath. 56: 580-581.

- \& KRUPINSKY, J. M. 1973. The effect of age on virulence of Septoria nodorum spores on wheat. Plant Dis. Reptr. 57: 363-366.

- , SCHAEFFER, G. W., KRUPINSKY, J. M. \& SHARPE, F. T. Jr. 1975. Effects of flag leaf axial lesions caused by Septoria nodorum on ${ }^{14} \mathrm{C}$ translocation and yield of wheat. Physiol. Plant Path. 6: 193-198.

- \& KRUPINSKY, J. M. 1978. Detection and manipulation of resistance to Septoria nodorum in wheat. Phytopath. 68: 245-248.

- \& EYAL, Z. 1980. Measurement of quantitative resistance to Septoria nodorum in wheat. Plant Disease 64: 492-496.

SCOTT, P. R. 1973. Incidence and effects of Septoria nodorum on wheat cultivars. Ann. appl. Biol. 75 : 321-329.

— \& BENEDIKZ, P. W. 1977. Field techniques for assessing the reaction of winter wheat cultivars to Septoria nodorum. Ann. appl. Biol. 85: 345-358.

- , BENEDIKZ, P. W. \& COX, C. J. 1982. A genetic study of the relationship between height, time of ear emergence and resistance to Septoria nodorum in wheat. Plant Path. 31: 45-60.

SHIPTON, W. A., BOYD, W. R. R., ROSIELLE, A. A. \& SHEARER, B. J. 1971. The common Septoria diseases of wheat. Bot. Rev. 37: 231-262.

STABEL, C. 1977. Den ekonomiske betydning af plantesygdommens og skadedyrenes bekampelse i lantbruket. Ugeskrift. Agron. Hort. Forst. og Lic. 1977, 35: 735-746.

SUNDELL, B. 1979. Växtskadegörare i jordbruket. Delrapport 2. Ekonomisk värdering av olika bekämpingsåtgärder. Inst. Ekon. Statist. Rapp. 151.

UBELS, E. 1979. A method to test wheat leaves for their reactions to inoculation with Septoria species. Neth. J. Pl. Path. 85: 143-150.

Ms received April 29, 1983 


\title{
Kevätvehnälajikkeiden ja jalostuslinjojen alttius Septoria nodorum Berk. -taudille.
}

\author{
Reijo Karjalainen
}

Kasvipatologian ja kasvinjalostustieteen laitos, Helsingin yliopisto, 00710 Helsinki 71

Aino Laitinen ja Tapio Juuti

Hankkijan Kasvinjalostuslaitos, 04300 Hyrylä

Kevätvehnälajikkeiden ja jalostuslinjojen alttiutta Septoria nodorum Berk. -taudille sekä taudin seulontamenetelmiä tutkittiin Hankkijan Kasvinjalostuslaitoksen Anttilan koetilalla. Testissä saastutettiin keinotekoisesti pieniä koeruutuja ja todettiin, että kaikki kotimaiset lajikkeet olivat alttiita, kaikkein altteimpia aikaiset Apu, Hankkijan Ulla, Hankkijan linja 21600 sekä myöhäinen Tähti. Sen sijaan mm. ulkomaiset CI 12463, Pilot, Garnet, Norröna, Brodda, T 7347, 80149 ja Kadett osoittautuivat tautia hyvin kestäviksi.

Saastutustestin tulosten ja kenttähavaintoihin perustuvan taudinkestävyyden välillä oli selvä positiivinen korrelaatio. 1000-siemenen painon ja taudin ankaruuden välillä oli useimmilla alttiilla lajikkeilla voimakas negatiivinen korrelaatio, mutta myös joillakin kestävillä lajikkeilla siemenpaino selvästi aleni taudin vaikutuksesta. Useimmilla kestävillä lajikkeilla 1000 -siemenen painon ja taudin välinen korrelaatio oli kuitenkin heikko.

Tutkimuksesta ilmeni, että keinotekoinen saastutus on luotettava keino seuloa alttiit ja kestävät lajikkeet toisistaan, mutta luotettavan tuloksen saaminen edellyttää useiden kerranteiden käyttöä. 